\title{
A Study on the Relationship between Exchange Rate and Consumer Prices Based on ECM
}

\author{
Jun Liu ${ }^{*}$
}

School of Management, Hefei University of Technology, Hefei, Anhui, 230009, China

\begin{abstract}
One important issue of exchange rate pass-through is the extent to which exchange rate changes affect the prices. This paper studied the pass-through effect of movements in the RMB nominal exchange rate on consumer prices. In particular, we examined whether the exchange rate pass-through to consumer prices was complete or not, and the impact of exchange rate system reform had on the pass-through effect. To this end, the paper used the error correction model (ECM) to conduct an empirical analysis from the first season of 1994 to the last season of 2013 period. The results showed that the pass-through of exchange rate changes to consumer prices was incomplete. In the sample period, the exchange rate pass-through effect was on the overall downward trend. The exchange rate system reform caused structural changes in the pass-through effect. The overall pass-through effect was higher after the reform than before, and the passthrough was lagging. Finally, our results made suggestions to improve Chinese monetary policies.
\end{abstract}

Keywords: Consumer prices, exchange rate pass-through, exchange rate.

\section{INTRODUCTION}

Price stability has become an important objective of the government's macroeconomic policy. Since 2007, China's inflation was high, showing higher inflationary pressures. After the global financial crisis, the inflation rate fell, however, the major developed countries implemented quantitative easing monetary policy, inflation rose sharply. Significant fluctuations in the price level are the results of a variety of internal and external factors, with the increase of opening degree, the exchange rate has become an important channel for external shocks affecting the domestic economy. With the implementation of the exchange rate system reform, exchange rate volatility increased, after sustained appreciation of the longer period of time, the RMB exchange rate in the recent period appeared sharp depreciation. Exchange rate changes may cause fluctuations in the domestic price level, i.e. the exchange rate pass-through. Exchange rate passthrough is a hot issue in the field of international economics, in which, an important issue is the extent to which exchange rate changes affect the prices $[1,2]$.

In this paper, we investigated the pass-through effect of movements in the RMB exchange rate on consumer prices. In particular, we examined whether RMB exchange rate pass-through to consumer prices was complete or not, and the impact of the exchange rate system reform had on the pass-through effect. To the end, we applied the error correction model (ECM) to conduct an empirical analysis from the first season of 1994 to the last season of 2013 period. This method can efficiently capture both the long-term and shortterm dynamic changes in variables. It also maintains the long-term dynamic information of the relationship between variables, and ensures the effectiveness of the regression analysis. In the application, this paper introduced dummy variables into the model. Furthermore, it introduced monetary policy variable into the model, and selected foreign price index constructed to measure the cost of foreign exporters. This model took a lag respectively considering exchange rate and monetary policy variables have lagged effects on the price index. The results showed that the passthrough of exchange rate changes to consumer prices was incomplete. Long-term effect of exchange rate pass-through to consumer prices was -0.19 . The degree of exchange rate pass-through was quite slow. In the sample period, the exchange rate pass-through effect was on the overall downward trend. The exchange rate system reform caused structural changes in the pass-through effect. The overall pass-through effect was higher after the reform than before, and the passthrough was lagging.

The remaining parts of the article are organized as follows: Section 2 reviews and summarizes the existing literature; Section 3 presents a theoretical model that has been constructed for studying exchange rate pass-through to consumer prices; Section 4 presents the empirical results; Section 5 provides the main conclusions.

\section{LITERATURE REVIEW}

Theoretical studies on exchange rate pass-through dated back to the 1960s, when the incompleteness of exchange rate pass-through was considered to be among the principal reasons for the failure of the law of one price and purchasing power parity. Since the 1980s the micro perspective of incomplete exchange rate pass-through became dominant in theoretical research [3], they attached importance to the effect of markup in pricing-to-market, and the role of product 
differentiation in the slope of product demand curve, and their influence on the exchange rate pass-through effect, but at this phase studies were mostly based on the partial equilibrium model analysis and did not consider price stickiness and expectations. In the $1990 \mathrm{~s}$, researchers paid more attention to the macro level, literature [4] pioneered to introduce nominal price rigidities and market imperfections into a micro-founded dynamic general equilibrium model, to build a new open-economy macroeconomics (NOEM), providing a new perspective for studies on exchange rate pass-through.

Empirical studies on the exchange rate pass-through issue began in the 1980s. Most of the studies concerned the impact of exchange rate changes on import prices. Also part of studies focused on the impact of exchange rate changes on producer prices and consumer prices. There were some studies of exchange rate changes on sector-specific import or export prices. Studies had been concentrated mainly on developed countries, especially U.S., few of them had been done on developing countries $[5,6]$. Numerous studies concluded that exchange rate pass-through was incomplete, along the price chain, exchange rate pass-through rate decreased [7]. In addition, there were differences in the degree of exchange rate pass-through between industries and countries, the level of pass-through in developing countries was generally higher than developed ones. The study also found that the degree of exchange rate pass-through was not stable, but showed a downward trend over time, and the effects of exchange rate pass-through to import prices and consumer prices were appearing a downward trend $[8,9]$.

\section{THEORETICAL ANALYSIS}

Among existing studies, exchange rate pass-through models are mostly established on the basis of profit maximization of firms. This paper studied the relationship between exchange rate fluctuations and consumer prices, focusing on the pass-through mechanism of exchange rate changes to domestic consumer prices. By referring to literature [10], a new open economy macroeconomic model was employed. They believed that due to the presence of distribution sectors, distribution costs were not sensitive to exchange rate changes, leading to incomplete exchange rate pass-through to total consumer prices.

Assuming that products domestic consumers spending are divided into non-tradable $(\mathrm{N})$ and tradable $(\mathrm{T})$ products, consumption of non-tradable and tradable goods satisfies the constant elasticity of substitution utility function. $\alpha$ refers to consumption weight of trade goods, $\phi$ is the elasticity of substitution between non-traded and traded goods. Nontradable goods are produced by domestic manufacturers, tradable goods can be divided into domestic produced tradable goods $(\mathrm{H})$ and imported products $(\mathrm{F}) . \alpha_{\mathrm{T}}$ denotes consumption weight of domestic tradable goods, $\phi_{\mathrm{T}}$ is the elasticity of substitution between domestic tradable goods and imported products.

The combination of total consumer goods and nontradable goods is:

$$
\begin{aligned}
& C_{t}=\left[\alpha^{\frac{1}{\phi}} C_{T t}^{\frac{\phi-1}{\phi}}+(1-\alpha)^{\frac{1}{\phi}} C_{N t}^{\frac{\phi-1}{\phi}}\right]^{\frac{\phi-1}{\phi}} \\
& C_{T t}=\left[\alpha_{T}^{\frac{1}{\phi_{T}}} C_{H t}^{\frac{\phi_{T}-1}{\phi_{T}}}+\left(1-\alpha_{T}\right)^{\frac{1}{\phi_{T}}} C_{F t}^{\frac{\phi_{T}-1}{\phi_{T}}}\right]^{\frac{\phi_{T}-1}{\phi_{T}}}
\end{aligned}
$$

So, the total consumer prices and the price of tradable goods are:

$$
\begin{aligned}
& \mathrm{P}_{t}=\left[\alpha \mathrm{P}_{\mathrm{T} t}^{1-\phi}+(1-\alpha) \mathrm{P}_{\mathrm{N} t}^{1-\phi}\right]^{\frac{1}{1-\phi}} \\
& \mathrm{P}_{\mathrm{T} t}=\left[\alpha_{\mathrm{T}} \mathrm{P}_{\mathrm{H} t}^{1-\phi_{\mathrm{T}}}+\left(1-\alpha_{\mathrm{T}}\right) \mathrm{P}_{F t}^{1-\phi_{\mathrm{T}}}\right]^{\frac{1}{1-\phi_{\mathrm{T}}}}
\end{aligned}
$$

where $\mathrm{P}_{\mathrm{H} t}, \mathrm{P}_{F t}, \mathrm{P}_{\mathrm{N} t}$ denote consumer prices of domestic tradable goods, imported products, domestic non-tradable goods respectively.

Supposing further that non-tradable goods, domestic tradable goods and imported goods both include products in a continuum of unit mass, respectively produced by a continuum of monopolistically competitive manufacturers, the elasticity of substitution between similar products is $\theta$. The combination of non-tradables, domestic tradable goods and imports respectively is: $C_{j}=\left[\int_{0}^{1} C_{j}(i)^{\frac{\theta-1}{\theta}} d i\right]^{\frac{\theta}{\theta-1}}, j=(N, H, F)$. So that the consumer demand function for a single product is: $C_{j t}(i)=\left[\frac{\mathrm{P}_{j t}(i)}{\mathrm{P}_{j t}}\right]^{-\theta} C_{j t}, j=(N, H, F)$.

In the face of consumer demand, monopolistically competitive manufacturers are respectively setting prices to maximize their profits. The profit maximization function of non-traded firms is:

$\Pi_{\mathrm{N} t}(i)=\mathrm{P}_{\mathrm{N} t}(i) C_{\mathrm{N} t}(i)-M C_{\mathrm{N} t} C_{\mathrm{N} t}(i)$

Assuming that domestic production consists of two parts, the part is domestic inputs, here we assume labor input; another part is certain imported inputs, $\mu_{\mathrm{N}}$ means share of imports required for the production of unit non-tradable goods. $\mu_{\mathrm{N}}$ refers to a function of exchange rate, changes in exchange rates will affect the ratio of imported inputs used by manufacturers. From (5) under an order condition can be obtained:

$$
\mathrm{P}_{N t}=\frac{\theta}{\theta-1} M C_{N t}=\frac{\theta}{\theta-1}\left[\frac{W_{t}}{Z_{N}}+\mu_{N}\left(E_{t}\right) \frac{E_{t} W_{t}^{*}}{Z_{F}}\right]
$$

where $W_{t}$ indicates domestic unit labor wages, $W_{t}^{*}$ means foreign labor wages, $Z$ means the level of productivity of 
various sectors. $E$ denotes the exchange rate, that domestic currency price of foreign currency.

Because tradable goods require a certain percentage of non-tradable goods as distribution costs in the sales process. Assuming that sales of per unit of domestic tradable goods and imports need $m_{H}$ and $m_{F}$ units of non-tradables. The share of distribution costs is a function of the exchange rate, affected by the exchange rate. Under these assumptions,

$\mathrm{P}_{H t}=\frac{\theta}{\theta-1} M C_{H t}=\frac{\theta}{\theta-1}\left[\begin{array}{l}\frac{W_{t}}{Z_{H}}+m_{H}\left(E_{t}\right) P_{N t} \\ +\mu_{H}\left(E_{t}\right) \frac{E_{t} W_{t}^{*}}{Z_{F}}\end{array}\right]$

$\mathrm{P}_{F t}=\frac{\theta}{\theta-1} E_{t} * M C_{F t}^{*}=\frac{\theta}{\theta-1}\left[\frac{E_{t} W_{t}^{*}}{Z_{F}}+m_{F}\left(E_{t}\right) P_{N t}\right]$

where $\mu_{H}$ represents share of imported inputs per unit of tradable goods. $\mu_{H}$ is also a function of the exchange rate, affected by the exchange rate.

From (6), (7), (8) can be drawn that the elasticities of exchange rate pass-through to consumer prices of home nontradable goods, tradable goods and imports are:

$$
\begin{aligned}
& \eta^{P_{N}, E}=\frac{\partial P_{N} / \partial E}{P_{N} / E}=\frac{\theta}{\theta-1}\left(1+\eta^{\mu_{N}(E), E}\right)\left[\frac{\mu_{N}(E) \frac{E W^{*}}{Z_{F}}}{P_{N}}\right] \\
& \eta^{P_{H}, E}=\frac{\partial P_{H} / \partial E}{P_{H} / E}=\frac{\theta}{\theta-1}\left[\begin{array}{c}
\left(\eta^{m_{H}(E), E}+\eta^{P_{N}, E}\right) \frac{m_{H}(E) P_{N}}{P_{H}} \\
+\left(1+\eta^{\mu_{H}(E), E}\right) \frac{\mu_{H}(E) \frac{E W^{*}}{Z_{F}}}{P_{H}}
\end{array}\right] \\
& \eta^{P_{F}, E}=\frac{\partial P_{F} / \partial E}{P_{F} / E}=1-\frac{\theta}{\theta-1}\left(\frac{m_{F}(E) P_{N}}{P_{F}}\right)\left[1-\left(\begin{array}{c}
\eta^{m_{F}(E), E} \\
+\eta^{P_{N}, E}
\end{array}\right)\right]
\end{aligned}
$$

From (9), (10), (11) can be seen that exchange rate passthrough into consumer prices of tradable goods only through imported inputs, the price of home tradables can respond to exchange rate through two channels: imported inputs in production and distribution sectors. The existence of distribution sectors reduces the proportion of imported parts in the final consumer prices. The magnitude of this effect depends on whether the distribution sectors make up, and whether the price of non-tradables responds to the exchange rate.

Further from (9), (10), (11) and (3), (4) can be drawn on the pass-through of exchange rate into the aggregate consumer prices:

$\eta^{P, E}=\alpha\left(\frac{P_{T}}{P}\right)^{1-\phi} \eta^{P_{T}, E}+(1-\alpha)\left(\frac{P_{N}}{P}\right)^{1-\phi} \eta^{P_{N}, E}$

$$
\begin{aligned}
\eta^{P, E} & =(1-\alpha)\left(\frac{P_{N}}{P}\right)^{1-\phi} \eta^{P_{N}, E}+\alpha\left(\frac{P_{T}}{P}\right)^{1-\phi}\left(\frac{P_{H}}{P_{T}}\right)^{1-\phi_{T}} \eta^{P_{H}, E} \\
& +\alpha\left(\frac{P_{T}}{P}\right)^{1-\phi}\left(1-\alpha_{T}\right)\left(\frac{P_{F}}{P_{T}}\right)^{1-\phi_{T}} \eta^{P_{F}, E}
\end{aligned}
$$

when $\phi=\phi_{T}$, equation (13) becomes

$$
\begin{aligned}
\eta^{P, E} & =\alpha * \alpha_{T}\left(\frac{P_{H}}{P}\right)^{1-\phi} \eta^{P_{H}, E}+\alpha\left(1-\alpha_{T}\right)\left(\frac{P_{F}}{P}\right)^{1-\phi} \eta^{P_{F}, E} \\
& +(1-\alpha)\left(\frac{P_{N}}{P}\right)^{1-\phi} \eta^{P_{N}, E}
\end{aligned}
$$

From (12), (13), (14) can be seen that the pass-through elasticity of exchange rate into the aggregate consumer prices is a weighted average of pass-through elasticities into traded and non-traded prices, both of which depend on the relative wage and productivity parameters, the elasticity of substitution between products, imported input used in domestic production, and distribution costs. Therefore, the pass-through elasticity of the aggregate consumer prices depends on the price elasticity, consumption shares, imported inputs, and distribution costs. Because of distribution sectors, distribution costs are not sensitive to exchange rate fluctuations, so that pass-through of movements in the exchange rate to final consumer prices is incomplete, resulting in incomplete exchange rate pass-through to aggregate consumer prices.

\section{ECONOMETRIC MODEL AND EMPIRICAL ANALYSIS}

\subsection{Model Specification}

According to the theoretical model of exchange rate passthrough and practices of previous studies, we established the pass-through equation of the relationship between consumer prices and exchange rate changes:

$$
\begin{aligned}
L C P I_{t} & =\beta_{0}+\beta_{1} * L N E R_{t}+\beta_{2} * L M 2_{t} \\
& +\beta_{3} * L G D P_{t}+\beta_{4} * L W P I_{t}+\varepsilon_{t}
\end{aligned}
$$

$(\mathrm{t}=1,2,3 \ldots \mathrm{n})$

where LCPI, LNER, LM2, LGDP, and LWPI respectively refer to the consumer price index, the RMB nominal effective exchange rate, money supply, gross domestic product, and foreign price index. All of the variables are expressed in logarithms.

LCPI, LNER, LM2, LGDP, and LWPI I(1) and certain linear combinations of the variables are stationary. We can make use of $\varepsilon_{t}$ generated from equation (15) to construct an error correction model. The model settings are as follows:

$$
\begin{aligned}
\Delta L C P I_{t}= & \sum_{i=0}^{\rho} \alpha_{1 i} * \Delta L N E R_{t-i}+\sum_{i=0}^{q} \alpha_{2 i} * \Delta L M 2_{t-i} \\
& +\alpha_{3} * \Delta L G D P_{t}+\alpha_{4} * \Delta L W P I_{t}+\alpha_{5} * A R(1) \\
& +\alpha_{6} * \varepsilon_{t-1}+\mu_{t}
\end{aligned}
$$


where $\mathrm{p}, \mathrm{q}$ represent the LNER, LM2 lags respectively. Here, the lags are taken because of the lagging impact that the exchange rate and monetary policy changes have on the price index. This often manifests itself over several periods.

In 2005, China reformed the exchange rate regime by moving into a managed floating exchange rate system based on market supply and demand with reference to a basket of currencies, the exchange rate system appeared significantly changes. The exchange rate system reform had an important impact on the pass-through effect, followed by the empirical analysis of this impact. In this paper, by introducing dummy variables, we made a judgment compared with the passthrough elasticity before and after the reform.

Assuming that,

$$
D_{1}=\left\{\begin{array}{l}
0, \text { before the exchange rate system reform } \\
1, \text { after the exchange rate system reform }
\end{array},\right.
$$

We constructed the model as follows:

$$
\begin{aligned}
\Delta L C P I_{t}= & \alpha_{0}+\alpha_{1} * \Delta L N E R_{t}+\gamma_{1} * D_{1} * \Delta L N E R_{t} \\
& +\sum_{i=1}^{\rho} \alpha_{1 i} * \Delta L N E R_{t-i}+\sum_{i=0}^{q} \alpha_{2 i} * \Delta L M 2_{t-i}+\alpha_{3} * \Delta L G D P_{t} \\
& +\alpha_{4} * \Delta L W P I_{t}+\alpha_{5} * A R(1)+\alpha_{6} * \varepsilon_{t-1}+\mu_{t}
\end{aligned}
$$

We presented following hypotheses:

$H_{0}: \gamma_{1}=0$, meaning there are no statistical differences in the pass-through effect before and after the exchange rate system reform.

$H_{1}: \gamma_{1} \neq 0$, meaning there are statistically significant differences in the pass-through effect before and after the exchange rate system reform.

The above hypotheses will be tested in the empirical analysis. If the coefficients of the dummy variable are significant statistically then the null hypothesis will be rejected.

\subsection{Sources of Data and Processing}

With the use of Eviews 6.0, we selected quarterly data from the first season of 1994 to the last season of 2013 to conduct our empirical analysis. We selected the consumer price index as a proxy variable for consumer prices, and selected the nominal effective exchange rate as a proxy variable for the exchange rate, taking the indirect quotation, an increase of the index means exchange rate appreciation. By referring to literature [2], we utilized foreign price index as a proxy variable to measure the cost of foreign exporters. $W P I_{t}=\left(C P I_{t} * N_{e e r} /\right.$ Reer $\left._{t}\right)$, Neer and Reer denote nominal effective exchange rate and real effective exchange rate. By referring to literature [11], we introduced monetary policy, reflecting the monetary policy factor. Given the different base periods for the original data, we converted various indexes to the first season of 1994 as the base period. In order to eliminate the impact of seasonal factors, the variables were seasonally adjusted. China's consumer price index, money supply and GDP were derived from the China Economic Information Network statistics database. The effective exchange rate was obtained from the IMF International Financial Statistics (IFS).

\subsection{Empirical Analysis}

\subsubsection{Unit root test}

In order to produce more robust results when studying the relationship between variables, it is required for the LCPI, LNER, LM2, LGDP, and LWPI sequences to conduct a unit root (ADF) test. According to Information Criterion (AIC) and Schwarz Criterion (SC) we chose lags according to the principle of minimum. The null hypothesis is the case that a unit root is present. Table 1 shows the unit root test results.

The unit root test shows that at the $5 \%$ significance level, the LCPI, LNER, LM2, LGDP, and LWPI original series are non-stationary series. However, after the first difference they all become stationary series. Therefore, we can consider that

Table 1. ADF test results.

\begin{tabular}{|c|c|c|c|c|}
\hline Series & ADF Statistics & $\mathbf{1 \%}$ Level Threshold & $\mathbf{5 \%}$ Level Threshold & Test Results \\
\hline \hline LCPI & 0.809661 & -3.521579 & -2.901217 & Non-stationary \\
\hline LNER & -1.413978 & -3.516676 & -2.899115 & Non-stationary \\
\hline LM2 & -2.829509 & -4.07842 & -3.467703 & Non-stationary \\
\hline LGDP & -0.974219 & -4.07842 & -3.467703 & Non-stationary \\
\hline LWPI & -2.487888 & -4.085092 & -3.470851 & Stationary \\
\hline$\Delta$ LCPI & -5.030719 & -3.521579 & -2.901217 & Stationary \\
\hline$\Delta$ LNER & -6.098884 & -3.516676 & -3.469235 & Stationary \\
\hline$\Delta$ LM2 & -6.043741 & -4.081666 & -3.468459 & Stationary \\
\hline$\Delta$ LGDP & -7.80132 & -4.080021 & -3.471693 & Stationary \\
\hline$\Delta$ LWPI & -5.800193 & -4.086877 & & \\
\hline
\end{tabular}


the LCPI, LNER, LM2, LGDP, and LWPI are integrated with order 1 process.

\subsubsection{Co-Integration Analysis}

Since the premise of the error correction model is the presence of a co-integration relationship between variables, we need to conduct a co-integration test. This is explained by the fact that the variables are first difference stationary series. Then, we applied the EG two-step method to do a cointegration test for the variables to determine the long-term stable relationship among them. First, we performed the OLS regression model. Then we performed an ADF test for the residual sequence. Table 2 presents the results.

Table 2. Co-integration equation results.

\begin{tabular}{|c|c|c|}
\hline Variable & Coefficient & T-Statistics \\
\hline \hline LNER & $-0.19^{*}$ & -1.901 \\
\hline LM2 & $0.252^{* *}$ & 2.222 \\
\hline LGDP & $-0.555^{* * *}$ & -3.488 \\
\hline LWPI & $1.748^{* * *}$ & 4.774 \\
\hline C & 0.026 & 0.017 \\
\hline$R^{2}$ & \multicolumn{2}{|c|}{0.92} \\
\hline F statistics & \multicolumn{2}{|c|}{208.34} \\
\hline
\end{tabular}

Notes: $* * *, * *, *$ indicate statistical significance at the $1 \%, 5 \%, 10 \%$ levels, respectively.

The residuals of the regression equation above are stationary. Therefore, the model specification is reasonable. It indicates the presence of a long-term co-integration relationship between LCPI, LNER, LM2, LGDP and LWPI. The results also point out that the long-term exchange rate passthrough to consumer prices is not complete. Meanwhile, the pass-through effect of RMB exchange rate on consumer prices is -0.19 . This means that the RMB nominal effective exchange rate appreciates by $1 \%$ and consumer prices fall 0.19 percentage points.

From literature abroad, it can be seen that the effect of exchange rate pass-through to consumer prices is quite low.
Literature [12] showed that in the long-term the level of exchange rate pass-through to European countries' consumer prices was, in order, France -0.07 , Germany -0.08 , Italy 0.12 , Netherlands -0.11 , Span -0.08 . Visibly, the degree of exchange rate pass-through in China is greater than developed countries.

Compared with other developing countries, literature [13] showed that long-term pass-through elasticities of consumer prices in Asian countries were respectively Indonesia -0.57 , Korea -0.13 , Philippines -0.15 , Thailand -0.26 , Singapore 0.2 . As can be seen from that the result of China is approximate to these countries. By contrast, the level of exchange rate pass-through in developing countries is greater than developed ones. As a developing country, China does not constitute an exception.

To further examine the specific changes in the process of pass-through coefficients, we applied the rolling regression method to conduct an analysis. Figure shows, the length of the rolling regression sample taken in the figure is 40 quarters, the sample time spans 1994Q1-2013Q4, a total of 80 quarters, we get 41 pass-through coefficients. In Fig. (1) can be found in the sample period, pass-through coefficients fluctuate up and down, showing the overall downward trend. So, how do we account for this phenomenon? This paper tries to discuss it from the inflationary environment perspective.

According to monetary policy report released by Bank of Canada in November 2000 that the low inflation environment will change the pricing behaviour of exporters. When the inflation rate continues to remain at a low level, people will think the central bank to maintain low inflation. Monetary policy is credible, low inflation is expected to persist. As a result, firms will not easily change the cost thanks to the economic shocks to transfer to the final part of consumer prices. First, menu cost considerations from price adjustment; Second, if enterprises transfer cost changes to the prices, the central bank will take policy measures to maintain a stable price level, companies may face a lack of market share. For China, before the third quarter of 1997, the level of inflation was greater, the average inflation rate reached $14.74 \%$, of which, in 1994 the inflation rate came up to $21.7 \%$. During this period, inflation expectations rose, monetary policy credibility declined, in this case, the pass-through

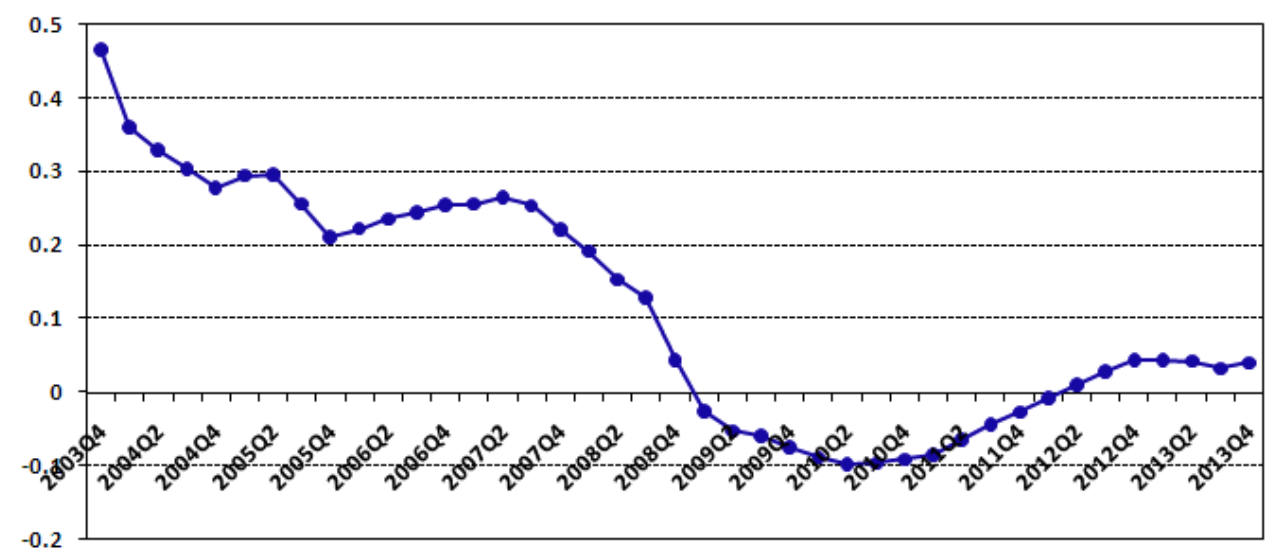

Fig. (1). Rolling regression pass-through coefficients. 
effect of exchange rate changes to price levels was relatively prominent. After the fourth quarter of 1997, because of the impact of the financial crisis and lack of domestic demand, economic growth was slow, price levels dropped significantly, inflation was expected to change, at this stage, the level of exchange rate pass-through was relatively low. After the second quarter of 2003, signs of inflation appeared in the economy, but compared with the early 1990s, the level of inflation was lower during this period, the average inflation rate was $3 \%$. Since the second half of 2008 , affected by the international financial crisis, economic growth declined, the price level fell sharply. Entering the period of the postfinancial crisis, the pace of economic growth slowed, inflation was at a low level, in this environment companies absorbing exchange rate fluctuations while keeping prices unchanged would be a wise choice, the exchange rate passthrough effect was relatively small.

\subsubsection{The Impact of Exchange Rate System Reform on the Pass-Through Effect}

Based on before and after exchange rate system reform in the model (17), that is bounded by the third quarter of 2005 , by comparing the pass-through elasticity estimates, we examined if there were differences in the extent of exchange rate pass-through to consumer prices. By executing the software, we obtained the following results.

Table 3 shows that, before the reform the RMB exchange rate pass-through elasticity of consumer prices is -0.05 , after the reform the pass-through rate is -0.077 . Visibly the response of consumer prices is negative, the exchange rate system reform has different impacts on the pass-through effect, the level of exchange rate pass-through after the reform is greater than before. The hypothesis $\mathrm{H}_{1}$ holds. This suggests that the pass-through effect of exchange rate changes on consumer prices, due to the adjustment of the exchange rate system, on the whole gradually and significantly enhances. In this regard, we believe that before the reform, sustainable balance of payments surplus formed ardent expectations of RMB appreciation in the market, with the influx of short-term capital. After the reform RMB exchange rate flexibility enhanced, exchange rate changes better reflected the supply and demand of foreign exchange in the market, effectively easing the pressure of RMB appreciation for a long time, but also helped to alleviate the strong expectations of further appreciation from home and abroad, to reduce foreign capital inflows, relatively improving the tightening effect of long-term RMB appreciation on consumer prices, resulting in an increase in the exchange rate passthrough effect.

\subsubsection{Impulse Response Function Analysis}

To further illustrate the impact of the reform has on the pass-through effect, the next we made the impulse response function analysis. Impulse response function (IRF) could measure the magnitude and time of the impact of a standard deviation (innovation) from a random disturbance term on current or future values of variables. This paper made an analysis in the VAR system. We separately estimated VAR before and after the reform, examining responses of consumer prices to exchange rate disturbances, and then compared the two reactions.

Table 3. The pass-through effect before and after the reform.

\begin{tabular}{|c|c|c|c|c|}
\hline & \multicolumn{2}{|c|}{ Before the Reform } & \multicolumn{2}{c|}{ After the Reform } \\
\hline Variable & Coefficient & T-Statistics & Coefficient & T-Statistics \\
\hline \hline$\Delta$ LNER & $-0.05^{* *}$ & -2.201 & $-0.077^{*}$ & -1.968 \\
\hline$\Delta$ LNER(-1) & 0.02 & 0.479 & -0.073 & 2.304 \\
\hline$\Delta$ LM2 & $-0.043^{*}$ & -1.79 & $0.021^{* *}$ & -1.686 \\
\hline$\Delta$ LM2(-1) & 0.047 & 0.772 & $-0.121^{*}$ & 2.004 \\
\hline$\Delta$ LGDP & -0.131 & -1.219 & $0.508^{*}$ & 5.369 \\
\hline$\Delta$ LWPI & $0.987^{* * *}$ & 18.981 & $0.746^{* * *}$ & -2.916 \\
\hline ECM(-1) & $-0.298^{*}$ & -1.734 & $-0.696^{* * *}$ & 2.817 \\
\hline AR(1) & $0.751^{* * *}$ & 6.663 & $0.567^{* *}$ & 0.79 \\
\hline$R^{2}$ & & & & 1.94 \\
\hline DW & & 0.91 & & \\
\hline
\end{tabular}

Notes: ${ }^{* * *},{ }^{* *}, *$ indicate statistical significance at the $1 \%, 5 \%, 10 \%$ levels, respectively.

Table 4. Cumulative impulse response results.

\begin{tabular}{|c|c|c|c|c|c|c|c|}
\hline Time & $\mathbf{1}$ & $\mathbf{2}$ & $\mathbf{3}$ & $\mathbf{4}$ & $\mathbf{5}$ & $\mathbf{6}$ & $\mathbf{7}$ \\
\hline \hline Before & 0.000000 & -0.002259 & -0.005834 & -0.008086 & -0.010260 & -0.011655 & -0.012997 \\
\hline After & 0.000000 & -0.003449 & -0.007835 & -0.010855 & -0.012510 & -0.014372 & -0.019698 \\
\hline
\end{tabular}


As can be observed in the above Table 4, for the exchange rate shock, the responses of prices are negative. Moreover, the reactions are lagging, with time going on, the cumulative responses of prices enhance. It can be found responses of consumer prices on the whole are higher after the reform than before, and in different periods are higher than the level before the reform.

\section{CONCLUSION}

Exchange rate pass-through is a hot issue in the field of international economics. This paper studied the influence of RMB nominal exchange rate changes had on consumer prices. We applied the error correction model (ECM) to perform an empirical analysis on quarterly data from the first season of 1994 to the last season of 2013. The results showed that the pass-through of RMB exchange rate changes to consumer prices was incomplete. In the long term, the pass-through elasticity of exchange rate fluctuations to consumer prices was -0.19 . The degree of exchange rate passthrough was quite slow. In the sample period, the exchange rate pass-through effect was on the overall downward trend. The exchange rate system reform caused structural changes in the pass-through effect. The overall pass-through effect was greater after the reform than before, and the passthrough was lagging.

\section{CONFLICT OF INTEREST}

The author confirms that this article content has no conflict of interest.

\section{ACKNOWLEDGEMENTS}

This work is supported by the project of the National Social Science Fund, China (No.12BJY157).

\section{REFERENCES}

[1] C. Betts, and M. B. Devereux, "Exchange rate dynamics in a model of pricing-to-market," Journal of International Economics, vol. 50, pp. $215-244,2000$

[2] J. M. Campa, and L. S. Goldberg, "Exchange rate pass-through into import prices," The Review of Economics and Statistics, vol. 87, pp. 679-690, 2005.

[3] R. Dornbusch, "Exchange rates and prices," American Economic Review, vol. 77, pp. 99-106, 1987.

[4] M. Obstfeld, and K. Rogoff, "Exchange rate dynamics redux," The Journal of Political Economy, vol. 103, pp. 624-660, 1995.

[5] J. Menon, "Exchange rate pass-through," Journal of Economic Surveys, vol. 9, pp. 197-231, 1995.

[6] H. Bouakez, and N. Rebei, "Has exchange rate pass-through really declined? Evidence from Canada," Journal of International Economics, vol. 75, pp. 249-267, 2008.

[7] N. Banik, and B. Biswas, "Exchange rate pass-through in the U.S. automobile market: a cointegration approach," International Review of Economics and Finance, vol. 16, pp. 223-236, 2007.

[8] K. Barhoumi, "Differences in long run exchange rate pass-through into import prices in developing countries: an empirical investigation," Economic Modelling, vol. 23, pp. 926-951, 2006.

[9] J. Beirne, and M. Bijsterbosch, "Exchange rate pass-through in central and eastern European EU Member States," Journal of Policy Modeling, vol. 33, pp. 241-254, 2011.

[10] L. S. Goldberg, and J. M. Campa, "The sensitivity of the CPI to exchange rates: distribution margins, imported inputs, and trade exposure," The Review of Economics and Statistics, vol. 92, pp. 392407, 2010.

[11] D. C. Parsley, and H. Popper, "Exchange rates, domestic prices, and central bank actions: recent U.S. experience," Southern Economic Journal, vol. 64, pp. 957-972, 1998.

[12] F. Hüfner and M. Schröder, "Exchange rate pass-through to consumer prices: a European perspective," Centre for European Economic Research, Available from: http://ssrn.com/abstract=304939. 2002.

[13] T. Ito, and K. Sato, "Exchange rate changes and inflation in PostCrisis Asian economies: vector autoregression analysis of the exchange rate pass-through," Journal of Money, Credit and Banking, vol. 40, pp. 1407-1438, 2008.

\author{
Received: June 10, 2015 \\ Revised: July 29, 2015 \\ Accepted: August 15, 2015 \\ (C) Jun Liu; Licensee Bentham Open.
}

This is an open access article licensed under the terms of the (https://creativecommons.org/licenses/by/4.0/legalcode), which permits unrestricted, noncommercial use, distribution and reproduction in any medium, provided the work is properly cited. 